\title{
Impact of implant insertion torque on success of implant-an evidence based review
}

\author{
Ajay Mahajan ${ }^{1, *}$, Kanwarjit Singh Asi $^{2}$, Shivanjli Bansal ${ }^{3}$, Deepa Rayast ${ }^{4}$ \\ ${ }^{1}$ Professor, ${ }^{2}$ Professor and Head, ${ }^{3,4}$ Junior Resident, Dept. of Periodontology, Himachal Pradesh Government Dental College and \\ Hospital, Shimla, Himachal Pradesh, India
}

*Corresponding Author:

Email: drajdent@yahoo.co.in

\begin{abstract}
Introduction: Insertion torque imposes a direct effect on the stability of implants. Some studies suggest that high torque has resulted in bone necrosis while some suggest no impact on bone with high torque, the literature regarding insertion torque relationship to changes in bone is sparse.

Purpose: The rationale of this article is to critically evaluate the available scientific data on influence of insertion torque on implant success.

Materials and Methods: A Medline and manual search was done to recognize studies that are concerned with insertion torque related implant success rates from 1970 to 2017. The articles taken in this study includes data on insertion torque such as primary stability, bone quality and quantity, implant design and changes in bone related to high or low torque.

Results: The 28 included studies contains one randomized controlled trial, 12 prospective studies and 10 retrospective studies. Conclusion: Insertion torque leads to primary stability of implants which ultimately contributes to implant success.
\end{abstract}

Keywords: Insertion torque, Primary stability, Bone density, Implant success.

\section{Introduction}

Nowdays, use of dental implants have turn out to be a popular treatment modality to replace missing tooth and have shown success rates beyond $90 \%$ in long term. ${ }^{1-2}$ Development in implant techniques have reduced the required healing time after implant loading. ${ }^{3}$ A dental implant is an alloplastic material used to anchor prosthetic replacement teeth in the edentulous jaw. ${ }^{4}$ The aim of implant therapy in dentistry is to restore tissue contour, function, comfort, esthetics and speech. ${ }^{5}$ The bone crest level around implant is of great importance to conclude osseointegrated implant success. ${ }^{6}$ Certain stresses on the repairing tissue in early or immediate loading of implants can promote fibrointegration during healing period and lead to implant failure so, protection of bone tissue from forces of occlusion is necessary. This helpful protection can be attained by reduction in micromovements at bone implant interface. ${ }^{7}$ Micromovements up to $150 \mathrm{um}$ are not harmful and has no effect on healing pattern of bone. ${ }^{8}$ For minimal micromovements splinted implants are good but splinting on more than one implant causes equal distribution of force on each implant. So, the minimum cut off value of micromovement shall not be achieved. ${ }^{3}$

Primary implant stability refers to a function of local bone characteristics, the design of an implant, the position and surgical procedure used, and the accurate fit in the bone. ${ }^{9}$ The objective to achieve primary stability during implant placement is to reduce undue micromotion at bone implant surface, which can interfere osseointegration. ${ }^{10}$ Methods to measure primary stability includes non-invasive methods such as periotest, Resonance Frequency Analysis (RFA) and the insertion torque. ${ }^{11}$
The force required to introduce a dental implant is called insertion torque (IT). It is the requisite torque to place the implant into the prepared osteotomy site. ${ }^{12}$ Oftenly a possible relationship between primary stability and implant insertion torque has been found in the dental literature. Several studies have used a common insertion torque as a marker of primary stability. ${ }^{10-15}$ The more the value of an insertion torque, the more the primary stability of the implant. ${ }^{3}$ Some clinicians prefer higher insertion torque whereas some suggest low. Few studies have indicated insertion torque near the range of $35 \mathrm{Ncm}$ to be satisfactory while some found no bone damage up to 176 $\mathrm{Ncm} \cdot{ }^{3,10,16,17}$ However, impact of high and low insertion torque depends on various parameters. ${ }^{18}$ In this review article we will discuss the effect of high insertion torque and bone related changes which ultimately decide the success and failure of an implant.

\section{Materials and Methods}

An investigation of the electronic database of PUBMED, up to and including 2017 was done. Studies included were randomized control trials, case series, case reports, review articles and systematic reviews.

The flow chart depicting the selection criteria and studies included is shown in Fig. 1. 


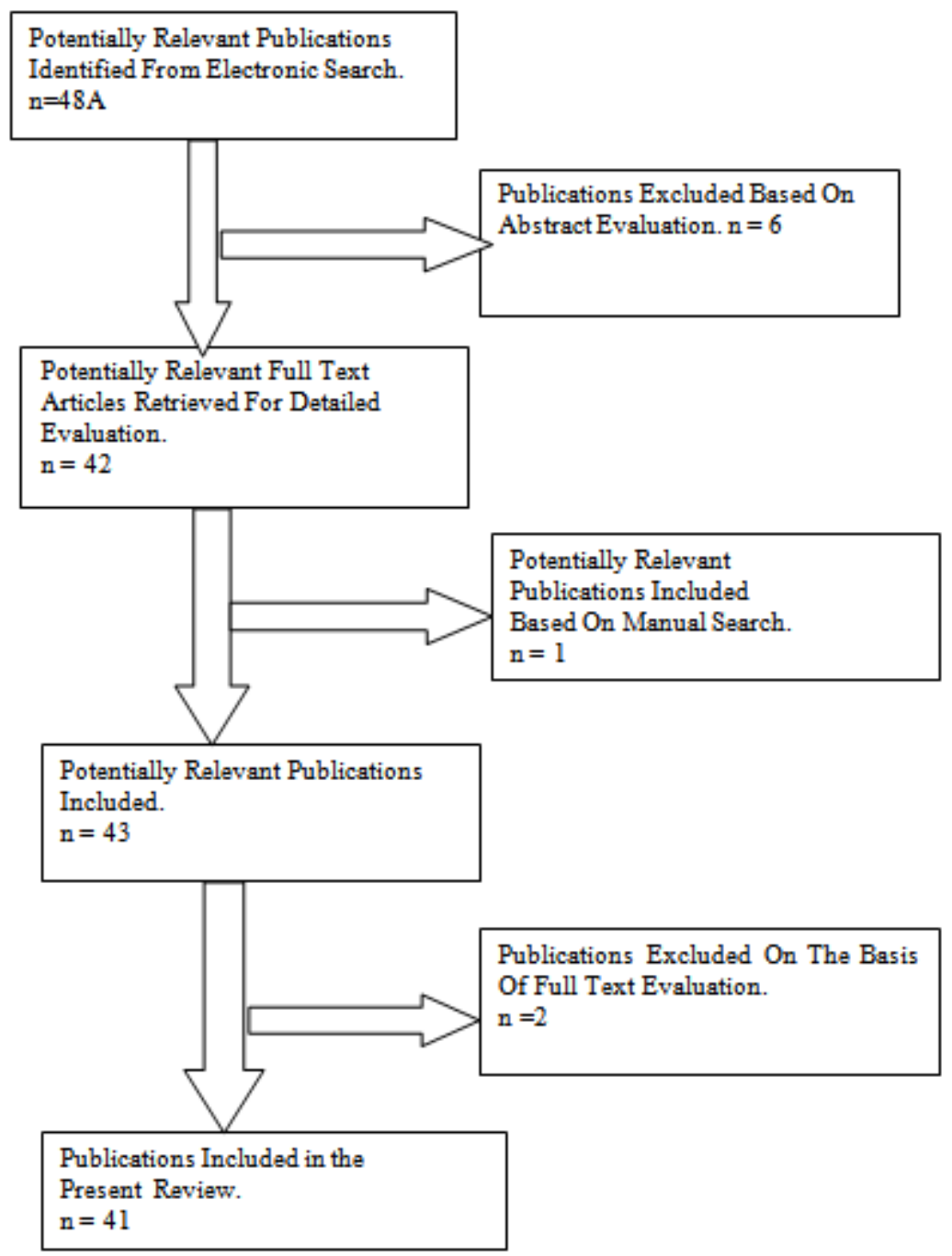

\section{Fig. 1: Flow chart showing selection process of the studies included in the systematic review}

Studies on insertion torque related to osseointegrated implant success included 23 RCT, 6 retrospective studies, 8 prospective studies, 8 review article, 2 meta-analysis and 1 literature review.

\section{What are the key factors affecting insertion torque?}

The factors affecting the insertion torque are - bone density, quality and quantity and hardness, using undersized drills and tapered designed implants. ${ }^{19}$ Primary stability of implants is influenced by two main factors which include residual bone at implant interface and the function of compressive stresses at the interface of implant-tissue. These stresses may prove useful to enhance implant's primary stability, but they can attain a elevated level that may cause necrosis and localised ischemia of the bone at the surface of implanttissue. ${ }^{9}$ Torque has a direct relationship with the density of the bone. ${ }^{19}$ At the time of placement of an implant the insertion torque plays a prime role to determine the initial stability, which serves as an essential factor for osseointegration of implants and immediate loading. ${ }^{20}$ The level of torque is generally expressed in Newton

centimeters $(\mathrm{Ncm}){ }^{3}$ Implant insertion torque can be assessed by electronic devices integrated with physiodispenser or with torque gauge incorporated with manual ratchets. ${ }^{11}$

Insertion torque not only describe the bone quality, rather it is an essential factor for the implant's primary stability and to decide the loading protocol, which in turn is an important factor which decides whether an implant will be successful or not. More value of insertion torque leads to more primary stability. ${ }^{11,15}$ Lower ranges have been associated with failures. ${ }^{21}$ Studies have indicated insertion torque near the range of $35 \mathrm{Ncm}$ to be satisfactory. ${ }^{22-24}$ Some authors demonstrated that higher insertion torque of an implant had no effect on hard and soft tissue while some reported necrosis and marginal bone resorption with higher torque. ${ }^{10,21,25-29}$ Some implant manufacturers suggest an insertion torque value that should not be 
exceeded or a minimum torque level to be attained for immediate implant loading still it is not clarified

what is that appropriate insertion torque value and if a threshold level of insertion torque does exist that could, eventually, induce bone resorption. ${ }^{11,30}$

Thus, several studies have been done to determine the association between insertion torque and bone related changes and have concluded a positive correlation between the two. ${ }^{10-20}$

The relation between insertion torque, osseointegration and implant success-an evidence based overview: Successful osseointegration is an outcome of good quality of primary stability which in turn depends on insertion torque ${ }^{31-33}$ Osseointegration is a structural and functional association between living bone and the loading implant interface, is crucial for implant stability, and is well thought-out a requirement for implant loading and clinical success of end osseous dental implants in long run. ${ }^{34}$ The success of an implant depends on interrelationship of various components which includes-implant surface and design, biocompatibility, surgical technique used, undisturbed healing phase and the most important by the quality and quantity of bone available. ${ }^{34}$ Although quantity of bone is definitely a crucial stricture the quality of bone seems to be even more important criterion in implant success. ${ }^{20}$ Lekholm and Zarb first described 4 types of bone quality namely type I-IV, where type I is the most dense and type IV is the poorest quality. The type I bone present in the anterior mandible has the best insertion torque values and implant stability and thus has highest success rates. Type III and type IV bone present in the posterior maxilla, has good primary stability but with high insertion torque values is not predictable, and the success rates cannot compare with those of the anterior mandible. ${ }^{35}$ Numerous studies support this association between quality of bone and long-term success. ${ }^{20,34,35}$

In recent years, modifications in implant design and surface have caused more success rates in all bone types. ${ }^{46-47}$ However, type IV bone has less long term success rates when compared with type I bone. ${ }^{48-49}$

A brief summary of the studies related to insertion torque and implant success is given in (Table 1). Success of an implant is attributed to osseointegration which takes place when micro movements are minimal. To keep micro movements minimal primary stability should be attained and to achieve primary stability insertion torque plays a vital role.

Insertion torque and primary stability both determines the osseointegrated implant success. According to various research papers, different torque values have been indicated as minimal and optimal, but there is no definitive torque value that lead to primary stability and above which bone necrosis resulting in peri implant bone resorption can occur. Further studies should be carried out to understand the impact of insertion torque on bone resorption.

Table 1:

\begin{tabular}{|c|c|c|}
\hline Author & $\begin{array}{l}\text { Type of Study } \\
\end{array}$ & Result \\
\hline Ottoni et al $(2005)^{[21]}$ & Controlled randomized: in vivo (humans) & $\begin{array}{c}\text { Average insertion torque in their study was } 38 \\
\mathrm{Ncm} \text { and successful osseointegration was } \\
\text { achieved. }\end{array}$ \\
\hline $\begin{array}{l}\text { Neugebauer et al } \\
(2006)^{[16]}\end{array}$ & Prospective: in vivo (minipig) & $\begin{array}{l}\text { Successful osseointegration observed when } \\
\text { average insertion torque was kept higher than } \\
35 \mathrm{Ncm} \text {. }\end{array}$ \\
\hline Duyck et al (2010) ${ }^{[36]}$ & Controlled randomized: in vivo (rabbits) & $\begin{array}{l}\text { Higher peri implant bone loss observed when } \\
\text { insertion torque was kept above } 50 \mathrm{Ncm} \text {. }\end{array}$ \\
\hline Makary et al $(2011)^{[37]}$ & Controlled randomized: in vivo (humans) & $\begin{array}{l}\text { The range of insertion torque was kept } \\
\text { between } 15 \text { to } 150 \mathrm{Ncm} \text { and found successful } \\
\text { outcomes in D1 to D4 type of bone. }\end{array}$ \\
\hline Trisi et al $(2011)^{[38]}$ & Controlled randomized: in vivo (sheep) & $\begin{array}{c}\text { Studied that higher IT (mean } 110 \mathrm{Ncm} \text { ) caused } \\
\text { no bone necrosis however increased primary } \\
\text { stability observed. }\end{array}$ \\
\hline Khayat et al $(2011)^{[10]}$ & Prospective: in vivo (humans) & $\begin{array}{l}\text { With use of high (upto } 176 \mathrm{Ncm} \text { ) no } \\
\text { deletirious effects insertion torque observed } \\
\text { on osseointegration. }\end{array}$ \\
\hline Campos et al (2012) ${ }^{[39]}$ & Controlled randomized: in vivo (dog) & $\begin{array}{l}\text { Range of IT was 130-160 Ncm and different } \\
\text { healing patterns of bone observed. }\end{array}$ \\
\hline Chai John et al (2012) ${ }^{[40]}$ & Controlled randomized: in vivo (humans) & $\begin{array}{l}\text { Concluded IT as viable mean to assess } \\
\text { mandibular bone quality in patient with } \\
\text { compromised bone density. }\end{array}$ \\
\hline $\begin{array}{l}\text { Cannizzaro et al } \\
(2012)^{[25]}\end{array}$ & Controlled randomized: in vivo (humans) & $\begin{array}{l}\text { At high insertion torque }(>80 \mathrm{Ncm}) \text { there was } \\
\text { less implant failures. }\end{array}$ \\
\hline Consolo et al $(2013)^{[41]}$ & Controlled randomized: in vivo (sheep) & $\begin{array}{l}\text { No significant differences in histological } \\
\text { evaluation, resonance frequency analysis, } \\
\text { removal torque. }\end{array}$ \\
\hline
\end{tabular}




\begin{tabular}{|c|c|c|}
\hline Hof et al $(2014)^{[42]}$ & Controlled randomized: in vivo (humans) & $\begin{array}{l}\text { No clinically significant differences in } \\
\text { marginal bone resorption after } 1 \mathrm{yr} \text { observed. }\end{array}$ \\
\hline Rea et al $(2015)^{[28]}$ & Controlled randomized: in vivo (dogs) & $\begin{array}{l}\text { The success rate of implants was more with } \\
\text { lower insertion torque as compared to higher } \\
\text { insertion torque. }\end{array}$ \\
\hline Rea et al $(2015)^{[29]}$ & Controlled randomized: in vivo (dogs) & $\begin{array}{c}\text { Similar type of osseointegration was observed } \\
\text { with high and low insertion torque. }\end{array}$ \\
\hline M. Wada et al (2016) ${ }^{[43]}$ & Review article & $\begin{array}{l}\text { Revealed bone density as a useful indicator of } \\
\text { implant success, preoperative CT may help to } \\
\text { predict the initial implant stability. }\end{array}$ \\
\hline Gehrke et al $(2016)^{[17]}$ & Controlled randomized: in vivo(humans) & $\begin{array}{l}\text { Their results proved } 35 \mathrm{Ncm} \text { as best IT value } \\
\text { for Conical internal connection. }\end{array}$ \\
\hline $\begin{array}{l}\text { Venkatakrishnan et al } \\
(2017)^{[44]}\end{array}$ & Short review & $\begin{array}{c}40 \mathrm{~N} \text { load in normal bone and } 32 \mathrm{~N} \text { load in } \\
\text { osteoporotic bone had same stress-strain } \\
\text { value. }\end{array}$ \\
\hline $\begin{array}{l}\text { Gary Greenstein et al } \\
(2017)^{[45]}\end{array}$ & Literature review & $\begin{array}{l}\text { Minimum torque to attain primary stability } \\
\text { not defined. With increasing IT }(>50) \text { no bone } \\
\text { damage observed and Implant micromotion } \\
\text { reduced. }\end{array}$ \\
\hline Grandi et al $^{[3]}$ & $\begin{array}{l}\text { Controlled Randomized: In } \\
\text { vivo(humans) }\end{array}$ & $\begin{array}{l}\text { When insertion torque used between } 30 \mathrm{Ncm} \\
\text { and } 100 \mathrm{Ncm} \text {, there was no difference in peri } \\
\text { implant bone resorption. }\end{array}$ \\
\hline
\end{tabular}

\section{Conclusion}

At the end of the study it was found that most of the studies used an insertion torque ranging $20-45 \mathrm{Ncm}$. A specific insertion torque value is still difficult to determine as the current evidence suggests the role of various other factors affecting insertion torque while implant placement.

\section{Refrences}

1. Albrektsson T, Zarb GA, Worthington P, Eriksson AR. The long-term efficacy of currently used dental implants: a review and proposed criteria of success. Int J Oral Maxillofac Implants. 1986;1:11-25.

2. Fugazzotto PA. Success and failure rates of osseointegrated implants in function in regenerated bone for 72 to 133 months. Int J Oral Maxillofac Implants. 2005;20:77-83.

3. Grandi T,Garuti G,Guazzi P,Sapio U,Forabosco A.A longitudinal,multicenter study on the relationship between insertion torque and peri-implant bone resorption.2011.

4. Fiorellini J,Wada K,Stathopoulou P,Klokkevold PR"Periimplant anatomy,Biology and function" In: Carranza FA, editor. Clinical Periodontology. 12th ed. p.1387.

5. Sargoizaie N, Arab HR, Moghaddam MM. Evaluation of creastal bone resorption around cylindrical and conical implants following 6 months of loading: a randomized clinical trial. Eur J Dent 2017;11:317-22.

6. Prasad DK,Shetty M,Bansal N,Hegde C. Crestal bone preservation:A review of different approaches for successful implant therapy. Indian J Dent Res 2011;22:317-23.

7. Szmukler-Moncler S,Salama S,Reingewirtz Y,Dubruille JH.Timing of loading and effect of micromotion on bone implant interface:a review of experimental literature.J Biomed Mat Res 1998;43(2):192-203.

8. Gehrke SA, da Silva UT, Del Fabbro M. Does Implant Design Affect Implant Primary Stability? A Resonance Frequency Analysis-Based Randomized Split-Mouth Clinical Trial. Oral Implantol. 2015 Dec;41(6):e281-6.
9. Bayarchimeg D, Namgoong H, Kim BK, Kim, M. D., Kim, S., Kim, T.-I.Kim, Koo K.-T. Evaluation of the correlation between insertion torque and primary stability of dental implants using a block bone test. Journal of Periodontal \& Implant Science. 2013;43(1):30-36.

10. Khayat PG, Arnal HM, Tourbah BI, Sennerby L. Clinical outcome of dental implants placed with high insertion torques (up to $176 \mathrm{Ncm}$ ). Clin Implant Dent Relat Res. 2013 Apr;15(2):227-33.

11. Goswami MM, Kumar M, Vats A, Bansal AS. Evaluation of dental implant insertion torque using a manual ratchet. Med J Armed Forces India. 2015 Dec;71(Suppl 2):S32732.

12. Cehreli MC, Karasoy D, Akca K, Eckert SE. Metaanalysis of methods used to assess implant stability. Int J Oral Maxillofac Implants. 2009;24:1015e1032.

13. Calandriello R, Tomatis M, Rangert B. Immediate functionalloading of Brånemark system implants with enhanced initial stability: a prospective 1- to 2-year clinical and radiographic study. Clin Implant Dent Relat Res 2003;5:10-20.

14. Beer A, Gahleitner A,Holm A, TschabitscherM,Homolka P.Correlation of insertion torques with bone mineral densityfrom dental quantitative $\mathrm{CT}$ in the mandible. Clin Oral Implants Res 2003;14:616-620.

15. Meredith N. Assessment of implant stability as a prognostic determinant. Int J Prosthodont 1998;11:491501.

16. Neugebauer J, Traini T, Thams U, Piattelli A, Zoller JE. Periimplant bone organization under immediate loading state. Circularly polarized light analyses: a Minipig study. J Periodontol.2006;77(2):152e160.

17. Gehrke SA, Shibli JA, Aramburú Junior JS, de Val JE, Calvo-Girardo JL, Dedavid BA. Effects of different torque levels on the implant-abutment interface in a conical internal connection. Braz Oral Res. 2016;30.

18. Berardini M, Trisi P, Sinjari B, Rutjes AW, Caputi S. The Effects of High Insertion Torque Versus Low Insertion Torque on Marginal Bone Resorption and Implant Failure Rates: A Systematic Review With Meta-Analyses. Implant Dent. 2016 Aug;25(4):532-40. 
19. Venkatakrishnan C.J,Bhuminathan S,Chandran C.R. Dental Implant insertion torque and bone density-short review.Biomed Pharmacol J 2017;10(3).

20. Irinakis $\mathrm{T}$, Wiebe $\mathrm{C}$. Initial torque stability of a new bone condensing dental implant. A cohort study of 140 consecutively placed implants. J Oral Implantol. 2009;35(6):277-82.

21. Ottoni JM, Oliveira ZF, Mansini R, Cabral AM Correlation between placement torque and survival of single-tooth implants. Int J Oral Maxillofac Implants. 2005 SepeOct;20(5):769e776.

22. Turkyilmaz I, McGlumphy EA. Influence of bone density on implant stability parameters and implant success: a retrospective clinical study. BMC Oral Health. 2008;8:32

23. da Cunha HA, Francischone CE, Filho HN, de Oleviera RC. A comparison between cutting torque and resonance frequency in the assessment of primary stability and final torque capacity of standard and TiUnite single-tooth implants under immediate loading. Int J Oral Maxillofac Implants. 2004;19(4):578e585.

24. Horwitz J, Zuabi O, Peled M, Machtei EE. Immediate and delayed restoration of dental implants in periodontally susceptible patients: 1 year results. Int J Oral Maxillofac Implants. 2007;22(3):423e429.

25. Cannizzaro G, Leone M, Ferri V, et al. Immediate loading of single implantsinserted flapless with medium or high insertion torque: A 6-month follow-up of a splitmouth randomized controlled trial. Eur J Oral Implantol. 2012;5:333-342.

26. Norton MR. The influence of insertion torque on the survival of immediately placed and restored single-tooth implants. Int J Maxillofac Implants. 2011;26:1333-1343.

27. Degidi M, Daprile G, Piattelli A. Implants inserted with low insertion torque values for intraoral welded full-arch prosthesis: 1-year follow-up. Clin Implant Dent Relat Res. 2012;14:e39-e45.

28. Rea M, Botticelli D, Ricci S, et al. Influence of immediate loading on healing of implants installed with different insertion torquesdan experimental study in dogs. Clin Oral Implants Res. 2015;26:90-95.

29. Rea M, Lang NP, Ricci S, et al. Healing of implants installed in over- or under-prepared sites-An experimental study in dogs. Clin Oral Implants Res. 2015;26:442-446.

30. Berardini M, Trisi P, Sinjari B, Rutjes AW, Caputi S. The Effects of High Insertion Torque Versus Low Insertion Torque on Marginal Bone Resorption and Implant Failure Rates: A Systematic Review With Meta-Analyses. Implant Dent. 2016 Aug;25(4):532-40.

31. Dos Santos MV, Elias CN, Cavalcanti Lima JH. The effects of superficial roughness and design on the primary stability of dental implants. Clin Implant Dent Relat Res. 2011;13:215-223.

32. Friberg B, Jemt T, Lekholm U. Early failures in 4,641 consecutively placed Branemark dental implants: a study from stage 1 surgery to the connection of completed prostheses. Int J Oral Maxillofac Implants. 1991;6:142146.

33. Cameron HU, Pilliar RM, Mac Nab I. The effect of movement on the bonding of porous metal to bone. $\mathbf{J}$ Biomed Mater Res. 1973;7:301-311.

34. Parithimarkalaignan S, Padmanabhan TV. Osseointegration: An Update. The Journal of the Indian Prosthodontic Society. 2013;13(1):2-6.

35. Lekholm U, Zarb GA. Patient selection and preparation. In: Branemark PI, Zarb GA, Albrektsson T, eds. Tissue Integrated Prostheses: Osseointegration in Clinical
Dentistry. Chicago, Ill: Quintessence Publishing Company; 1985:199-209.

36. Duyck J, Roesems R, Cardoso MV, et al. Effect of insertion torque on titanium implant osseointegration: An animal experimental study. Clin Oral Implants Res. 2015;26:191-196.

37. Makary C, Rebaudi A, Mokbel N, Naaman N. Peak insertion torque correlated to histologically and clinically evaluated bone density. Implant Dent.2011.; 20(3):182e191.

38. Trisi P, Todisco M, Consolo U, et al. High versus low implant insertion torque:A histologic, histomorphometric, and biomechanical study in the sheep mandible.Int $\mathrm{J}$ Maxillofac Implants. 2011;26:837-849.

39. Campos FE, Gomes JB, Marin C, et al. Effect of drilling dimension on implant placement torque and early osseointegration stages: an experimental study in dogs. J Oral Maxillofac Surg.2012; 70(1):e43ee50.

40. Chai J, Chau AC, Chu FC, Chow TW. Correlation between dental implant insertion torque and mandibular alveolar bone density in osteopenic and osteoporotic subjects. Int J Oral Maxillofac Implants2012.; 27(4):88893.

41. Consolo U, Travaglini D, Todisco M, et al. Histologic and biomechanical evaluation of the effects of implant insertion torque on peri-implant bonehealing. J Craniofac Surg. 2013;24:860-865.

42. Hof M, Pommer B, Strbac GD, et al. Impact of insertion torque and implant neck design on peri-implant bone level: A randomized split-mouth trial. Clin Implant Dent Relat Res. 2014;16:668-674.

43. M. Wada, T. Suganami, M. Sogo, Y. Maeda. Can we predict the insertion torque using the bone density around the implant? International Journal of Oral and Maxillofacial Surgery.2016; 45(2):221-225.

44. CJ Venkatakrishnan, S Bhuminathan, Chitraa R Chandran. Implant Insertion Torque Load Analysis for Mandible using CBCT Images. World J Dent.2017; 8(3):183-189.

45. G Greenstein et al. Implant Insertion Torque: Its Role in Achieving Primary Stability of Restorable Dental Implants. Compend Contin Educ Dent.2017; 38(2), 8895. 2.

46. Kline R, Hoar JE, Beck GH, Hazen R, Resnik RR, Crawford EA. A prospective multicenter clinical investigation of a bone qualitybased dental implant system. Implant Dent. 2002;11:224-234.

47. Friberg B, Jisander S, Widmark G, et al. One-year prospective three-center study comparing the outcome of a "softbone implant" (prototype Mk IV) and the standard Branemark implant. Clin Implant Dent Relat Res. 2003;5:71-77.

48. Vigolo P, Givani A, Majzoub Z, Cordioli G. A 4-year prospective study to assess peri-implant hard and soft tissues adjacent to titanium versus gold-alloy abutments in cemented single implant crowns. J Prosthodont. 2006;15:250-256.

49. Arlin ML. Survival and success of sandblasted, large-grit, acid etched and titanium plasma sprayed implants: a retrospective study. J Can Dent Assoc. 2007;73:821$821 \mathrm{f}$ 